\title{
Słodko-gorzki smak mistyki. Leksyka zmysłu smaku w Dzienniczku św. Faustyny Kowalskiej
}

Świat mistyka nie uznaje dualizmu, podziału na sacrum i profanum wszystko dla niego jest jedną, Bożą rzeczywistością. ,Ze wszystkiego wyciąga korzyść dla duszy" [Dz. 148], jakby powiedziała św. Faustyna². Wszystko zatem może być u niego podniesione do rangi symbolu (także zmysł smaku), prowadząc per visibilia ad invisibilia. Rzecz tę wybitnie ukazuje choćby św. Edyta Stein w swoim studium o Dionizym Areopagicie i w przekładzie jego tekstów. We wstępie do tego dzieła czytamy: „Poprzez tych, do których przemawia na szczycie góry, Bóg chce mówić do tych, których zostawili oni na dole. [...] A sam przemawia do innych jako «teolog symboliczny» - poprzez naturę, poprzez doświadczenie

1 Izabela Rutkowska, doktor nauk humanistycznych, językoznawca, logopeda, wykładowca PWSZ w Głogowie, członek Koła Współpracowników Zespołu Języka Religijnego Rady Języka Polskiego, redaktor naczelny Rocznika Nauk Społecznych PWSZ w Głogowie „Spotkania”, tłumacz z języka włoskiego, autorka książki Niepojęty świat duszy. Język doświadczeń mistycznych św. Faustyny Kowalskiej, Tarnów 2017. E-mail: i.rutkowska@pwsz.glogow.pl.

2 M. F. Kowalska, Dzienniczek. Miłosierdzie Boże w duszy mojej, Warszawa 2006. Z uwagi na to, iż tekst Faustyny jest podzielony na numerowane akapity, w artykule będzie używany stosowny skrót. 
wewnętrzne i poprzez owe ślady w ludzkim życiu i dziejach świata; tym sposobem umożliwia im rozumienie mowy teologów”3. Podobnie możemy powiedzieć o Faustynie, która pokazuje, że skarby sakralnej sfery ukryte są w codzienności. Jak pisze Andrzej Kominek: „usiłowała oddać swoje myśli i doświadczenia wiary nie za pomocą terminów teologicznych (bo tych nie znała), ale obrazowego języka egzystencjalnego"4.

Jednym z najistotniejszych pól symboliki religijnej jest w Dzienniczku ciało człowieka - jego cechy, funkcje, zmysły. Świadczy o tym sam obraz Jezusa, objawiony świętej 22 lutego 1931 roku, a przedstawiający całą Jego postać. Celem tego artykułu będzie odkrycie znaczeń, jakie św. Faustyna nadała zmysłowi smaku, a zarazem ukazanie poziomów metaforyzacji użytego przez nią słownictwa. Analiza dotyczyć będzie jedynie leksyki opisującej smaki słodki i gorzki (są to bowiem jedyne wymieniane przez Świętą nazwy smaków). Do przeprowadzenia analizy będzie zastosowana metodologia językowego obrazu świata (JOS). W tle zostaną nakreślone dostępny w Dzienniczku zasób słownictwa z badanej tematyki, a także dygresje odnoszące się do życia świętej oraz do zmysłu smaku jako cechy biologicznej i jego konotacji kulturowych.

Z biologii dowiadujemy się, że zmysł smaku ma człowiekowi służyć przede wszystkim do rozpoznawania składu chemicznego pokarmów w celu stwierdzenia, na ile są zdatne do spożycia, czy nie są trucizną. Generalnie przyjmuje się rozróżnienie na pięć smaków: słodki (lokalizuje węglowodany, cukry proste i dwucukry), słony (kationy soli sodu i potasu), kwaśny (kwasy organiczne i nieorganiczne), gorzki (alkaloidy i sole nieorganiczne) oraz umami (kwas glutaminowy, składnik większości białek). Ten ostatni, charakterystyczny głównie dla azjatyckich potraw, wprowadzony został w roku 2000, a rozpoznawany jest w takich produktach, jak np.: grzyby, pomidory, brokuły, orzechy. Nie są to jednak jedyne nazwy smaków. Jak przytacza Barbara Mitrenga, w polszczyźnie smaki

3 B. Beckmann, Wprowadzenie, w: Teresa Benedykta od Krzyża, Drogi poznania Boga, Kraków 2006, s. 15.

4 A. Kominek, Jak skutecznie przekazywać prawdę o miłosierdziu Bożym? Orędzie św. Faustyny Kowalskiej w praktyce katechetycznej, w: Komunikacja i tekst w perspektywie rozwojowej i dydaktycznej, red. J. Porayski-Pomsta, Warszawa 2005, s. 271 (Studia Pragmalingwistyczne, 4). 
określano także jako: ostry, tłusty, mdły, wodny, cierpki, lepki, obrzydliwy, metaliczny, alkaliczny 5 .

\section{Leksyka zmysłu smaku}

Językowy obraz ${ }^{6}$ wrażeń smakowych, nakreślony w Dzienniczku, obejmuje przede wszystkim nazwy smaków, ponadto nazwy potraw, które je generują, a także nazwy samych czynności jedzenia i picia czy też problemów związanych z głodem, pragnieniem lub trudnością w spożywaniu pokarmów. Konotacje te nas nie dziwią - znajdujemy je w opisach definicyjnych smaku: „zmysł, którego receptory znajdujące się głównie na języku pozwalają na rozpoznanie pewnych właściwości przyjmowanych pokarmów [...]; właściwość rzeczy, najczęściej jadalnych, działająca na ten zmysł [...]; chęć do jedzenia"'. Jak dowodzi Mitrenga, leksyka smakowa wchodzi w skład dwóch pól tematycznych (chodzi o podział polszczyzny na pola tematyczne według Andrzeja Markowskiego): „Działanie ciała, zmysły, choroby” oraz „Jedzenie i jego przyrządzanie”. Tym zaś, co stanowi specyfikę badanego tekstu, są konotacje religijne, nieujmowane zwykle w definicjach systemowych.

Poniższa tabela wskaże zebrane słownictwo w podziale na pola semantyczne ${ }^{9}$. Opisy wyróżnione pogrubioną czcionką wskazują na domenę pojęciową danego pola - te w poziomie dzielą słownictwo pod względem jego cech definicyjnych, te w pionie dzielą zaś słownictwo ze względu

5 B. Mitrenga, Zmyst smaku. Studium leksykalno-semantyczne, Katowice 2014, s. 26.

6 „Przez językowy obraz świata rozumiem zawartą w języku interpretację rzeczywistości, którą można ująć w postaci zespołu sądów o świecie. Mogą to być sądy bądź to utrwalone w samym języku, w jego formach gramatycznych, słownictwie, kliszowanych tekstach (np. przysłów), bądź to przez formy i teksty języka implikowane”. J. Bartmiński, Językowe podstawy obrazu świata, Lublin 2007, s. 76-77.

Uniwersalny słownikjęzyka polskiego, red. S. Dubisz. Warszawa 2003, s. 421-422.

B. Mitrenga, Zmyst smaku..., dz. cyt., s. 33.

9 „Pole semantyczne - uporządkowany wewnętrznie pod względem paradygmatycznym i syntagmatycznym zbiór leksemów reprezentujących zbiór pojęć związanych jakimś pojęciem nadrzędnym, np. pojęciem intelektu, piękna, pokrewieństwa”. Encyklopedia językoznawstwa ogólnego, red. K. Polański, Wrocław 2003, s. 444-445. 
na sposób użycia (takie, które można użyć zarówno w codziennych kontaktach jak i w kontekście religijnym, a także na takie, które jest nacechowane religijnie - jego frazeologia wprost odsyła nas do Biblii albo do liturgii Kościoła Katolickiego). Należy przy tym dodać, że słownictwo, które może funkcjonować w codziennych sytuacjach, w Dzienniczku zostało wykorzystane przede wszystkim do nakreślenia relacji duchowych. Nawet te fragmenty, które opisują realny posiłek, zanurzone są w kontekście religijnym, stanowiąc swoistą przypowieść, naukę.

\subsection{Smak słodki}

W Dzienniczku odnajdziemy tylko jedną nazwę smaku konotowanego jako przyjemny - słodki. Do jego pola semantycznego należą wyrazy: najsłodszy (30), słodzić (1), słodki (47), słodkość (2), słodycz (13).

Słodki jest przede wszystkim sam Jezus i wszystko, co z Nim związane. Mówią o tym wyrażenia: „najsłodszy Jezus”, „Oblubieniec”, „Pan”, „najsłodsze Imię Jezus”, „Miłosierdzie, Serce Jezusa”, „słodki Gość”, "Jezus”, „Mistrz”, „Oblubieniec”, „Wódz”, „Zbawiciel”, a także „słodki promień Boży". Słodka jest także Matka Boża. Takie nazewnictwo nas nie dziwi - występuje bowiem w modlitwach i pieśniach zamieszczanych w książeczkach do nabożeństwa, wyrażenie „słodki Jezu” przeszło wręcz do języka potocznego. Faustyna także znała je z własnej codzienności, a także z kościelnej, zakonnej tradycji. Niektóre z nich mają także proweniencję biblijną, jak frazy: „kosztować słodyczy Bożych”; ,poznajcie, jak słodki jest Pan”, które są kompilacją cytatów: „Skosztujcie i zobaczcie, jak dobry jest Pan" (Ps 34,9); ,jeżeli zasmakowaliście, jak słodki jest Pan” $(1 \mathrm{P} 2,3)^{10}$.

Poufne obcowanie duszy z Bogiem. Bóg zbliża się do duszy w sposób szczególny, wiadomy tylko Bogu i duszy. Nikt nie dostrzega tej tajemniczej łączności, w tej łączności przewodniczy miłość i dokonuje wszystkiego tylko miłość. Jezus udziela się duszy w sposób łagodny, słodki, a w głębi Jego jest spokój [Dz. 622, por. 961].

10 Wszelkie biblijne odwołania dotyczą wersji: Pismo Święte Starego i Nowego Testamentu, oprac. Zespół Biblistów Polskich z inicjatywy Benedyktynów Tynieckich, Poznań 2000. 
Słodko-gorzki smak mistyki...

\begin{tabular}{|c|c|c|}
\hline 恙志 & 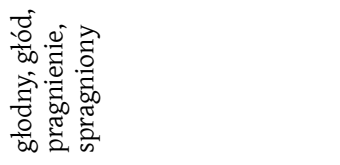 & 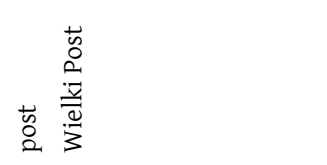 \\
\hline 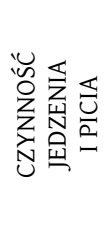 & 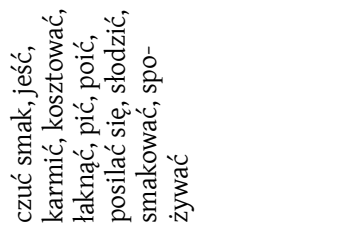 & 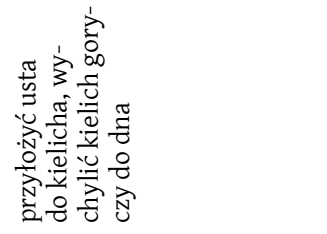 \\
\hline  & 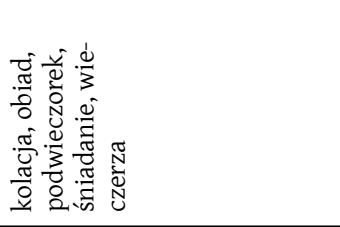 & 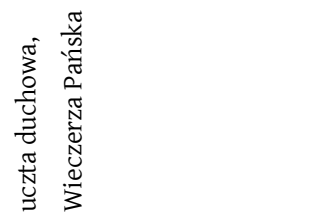 \\
\hline 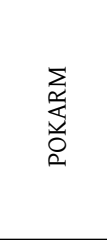 & 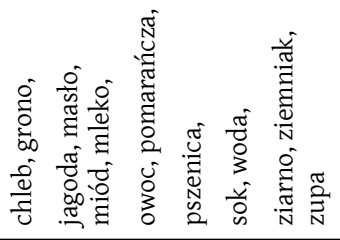 & 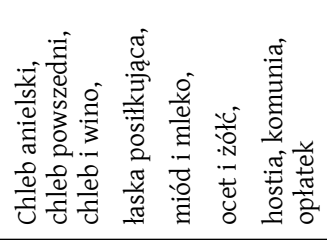 \\
\hline$\sum_{n}^{\infty}$ & 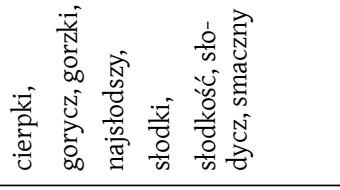 & 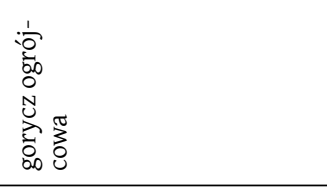 \\
\hline  & 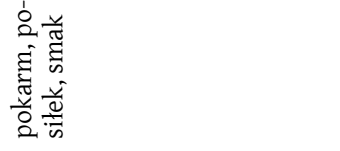 & \\
\hline 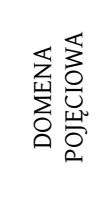 & 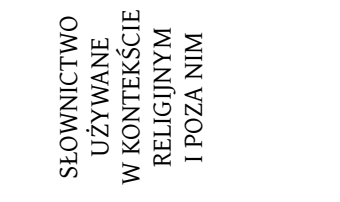 & 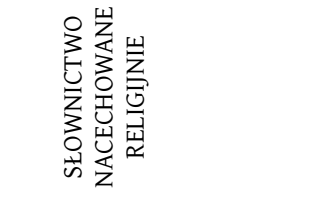 \\
\hline
\end{tabular}




O, jak dobrze jest odprawić rekolekcje przy najsłodszym Sercu Boga mojego. Jestem na puszczy ze swym Oblubieńcem, nikt mi nie przeszkadza w słodkiej rozmowie z Nim [Dz. 1330].

Dziś miłość Boża przenosi mnie w zaświaty. Jestem pogrążona w miłości, kocham i czuję, że jestem kochana, i całą świadomością to przeżywam. Tonie moja dusza w Panu, poznając wielki majestat Boży i maleńkość swoją, lecz przez to poznanie zwiększa się szczęście moje... Ta świadomość jest tak żywa w duszy, tak potężna, a zarazem tak słodka [Dz. 1500].

Podczas mistycznych spotkań święta ogląda „słodką twarz” Jezusa, doświadcza Jego „słodkiego spojrzenia”, a także „słodkiej rozmowy”, podczas której On „słodko słucha” jej słów.

Poza wymienionymi wyrażeniami i zwrotami znamienne jest połączenie leksyki słodkiego smaku z leksyką cierpienia (które zwykle konotuje smak gorzki). Połączenie takie informuje nas zatem, że musi chodzić o szczególny rodzaj cierpienia - cierpienia z miłości, znoszonego ze względu na osobę kochaną, w tym przypadku Jezusa. Oddają to pojedynczo użyte wyrażenia: ,słodka męka”, ,słodka uwaga”, ,słodka śmierć”, „słodkie konanie”; oraz frazy: „doznawać słodyczy w cierpieniu”, „słodko cierpieć dla Ciebie”, „słodko trudzić się dla Boga”. Sformułowania tego typu pojawiają się głównie w poezji miłosnej, w opisach wyznań. U św. Faustyny wyznawanie miłości jest jednocześnie chęcią upodobnienia się do Jezusa Ukrzyżowanego i współprzeżywania Jego męki.

O, wielka to dusza, gdy wśród cierpienia / Stoi wiernie przy Bogu i pełni Jego wolę, / I wśród największych tęcz i burz jest bez pocieszenia, / Bo c zysta miłość Boża słodzi jej dolę [Dz. 995].

Rozciągnęło się ciało moje na drzewie krzyża, wiłam się w strasznych boleściach do jedenastej. Przeniosłam się w duchu do tabernakulum i odkryłam puszkę, opierając swą głowę o brzeg kielicha, a wszystkie łzy spływały cichutko do Serca Tego, który jeden rozumie, co to ból i cierpienie; i doznałam słodyczy w tym cierpieniu, i zapragnęła dusza moja tego słodkiego konania, którego nie zamieniłabym za żadne skarby świata [Dz. 1454].

O Boże mój, jak słodko jest cierpieć dla Ciebie, cierpiećw najtajniejszych tajniach serca, w największym ukryciu, płonąć jako ofiara przez nikogo nie spostrzeżona, czysta jak kryształ, bez żadnych pociech ani współczucia [Dz. 351].

Nie tylko te fragmenty ukazują nam Faustynę jako kobietę zakochaną. Znamienne są także jej wyznania, iż z powodu tęsknoty za ukochanym Bogiem nie jest w stanie nic zjeść, nic jej nie smakuje: „Kiedy zasiadłam 
do śniadania bardzo smacznego - rzekłam do Pana: Dziękuję Ci za te dary, ale serce moje kona z tęsknoty za Tobą i nic mi nie smakuje, co z ziemi; pragnę pokarmu miłości Twojej" [Dz. 1026; por. Dz. 96]. W takich kontekstach wspomina o duchowym głodzie, niemożliwym do zaspokojenia przez jakiekolwiek ziemskie pokarmy - głodzie obecności Boga [por. Dz. 77; 1186].

Powyższe konteksty występowania badanej leksyki są zbieżne z kontekstami, jakie znajdujemy w źródłach staropolskich. Tam również słodki smak odnosił się do Boga, Jezusa i Maryi, służąc także do opisu męki Pańskiej ${ }^{11}$.

O odniesieniach do smaku słodkiego informują nas także nazwy pokarmów. I to one widnieją w indeksach słowników symboli, nie nazwy smaków. U Faustyny są nimi: miód (3) i owoc (7). Miód symbolizuje m.in. „łączność z bóstwem, boską miłość, jadło niebiańskie, pełne szczęście, najwyższe dobro ziemskie i niebieskie; obfitość; wiedzę, mądrość, wtajemniczenie; bogactwo duchowe" ${ }^{12}$. Już od czasów starożytnych uważany był za boski napój, a wyrabiające go pszczoły uznawano za emblemat nieśmiertelności (stąd m.in. balsamowanie miodem zwłok u Persów). Według mitologii hinduskiej pobożne dusze szukają pokrzepienia w miejscu nazywanym miodowe źródło. W mitologii greckiej karmiono nim Zeusa jako niemowlę. W Księdze Izajasza miód ma być pokarmem zapowiadanego Emmanuela (zob. Iz 7, 15) ${ }^{13}$.

Bóg nie udziela się duszy gadatliwej, która jak truteń w ulu wiele brzęczy, ale za to nie wyrabia miodu [Dz. 118]. Zgromadzenie to, Miłosierdzia Bożego, będzie w Kościele Bożym jako ul we wspaniałym ogrodzie; ukryte, ciche siostry jako pszczółki pracować będą, aby mi odem karmić dusze bliźnich, a wosk ma płynąć na cześć Boga [Dz. 664].

Oblubieńcze mój, Ty mnie karmisz mlekiem i miodem Serca swego; od najwcześniejszych lat wychowywałeś mnie sam dla siebie, abym umiała Cię teraz kochać [Dz. 1771].

\footnotetext{
11 B. Mitrenga, Zmyst smaku..., dz. cyt., s. 151-152.

12 W. Kopaliński, Słownik symboli, Warszawa 1999, s. 226.

13 M. Lurker, Słownik obrazów i symboli biblijnych, tłum. K. Romaniuk, Poznań 1989, s. 123.
} 
Faustyna wykorzystała dwojaką symbolikę miodu - owoc pracy oraz znak obfitości i szczęścia. Miód jako symbol pracy jest częścią opisu idealnego zakonu. W roku 1935 otrzymała bowiem w objawieniu misję założenia zgromadzenia wysławiającego Boże miłosierdzie. W Dzienniczku naszkicowała jego regułę, rozważając, czy powinna sama zająć się jego założeniem. Przyrównuje ów zakon do ula, bo - jak wiadomo - ul symbolizuje społeczność doskonałą. Modlitwy i ofiary sióstr tworzących taką społeczność mają być jak miód - pokarm łaski Bożej wspierający dusze bliźnich. W tym też mają być podobne do Zbawiciela, bo to przede wszystkim On karmi dusze słodyczą swego Serca. Motyw ula znajdującego się w Kościele nie jest nowy, choć jego wzmianka u św. Augustyna raczej nie była znana siostrze Faustynie. Według świętego z Hippony, „w Kościele jest przechowywany «ul pszczeli», z którego dzieci Boże biorą «słodki miód Chrystusa - czyli pokarm na życie wieczne»"14.

W drugim cytacie oczywiste jest odniesienie biblijne - wyrażenie mlekiem i miodem przenosi nas do Starego Testamentu, w którym ową krainą mlekiem i miodem płynącą był Kanaan, Ziemia Obiecana (zob. Wj 3, 10). U Faustyny tą szczęśliwą ziemią jest Serce Jezusa-Oblubieńca. To ono jest także nazwane źródłem słodyczy. Już ojcowie Kościoła określali Chrystusa skałą, z której wypływa miód ${ }^{15}$. Ów Chrystusowy eucharystyczny pokarm, jakim jest Komunia Święta, także przyrównywany był do miodu. Do VI wieku funkcjonował wręcz zwyczaj, aby po sakramencie chrztu i Eucharystii podawać nowemu członkowi Kościoła do wypicia mleko z miodem. Zwyczaj ten nadal obowiązuje w rycie koptyjskim i ormiańskim ${ }^{16}$.

Słodkim pokarmem jest także dojrzały owoc - efekt „symbiozy głębin ziemi i światła; z jednej strony skutek ziemskiego trudu, a z drugiej widzialny znak błogosławieństwa Bożego"17, symbol płodności i życia. Siostra Kowalska, która wychowywała się na wsi, a w zakonie była wyznaczona do prac w ogrodzie, wiedziała, że smak owoców zależy

14 M. Lurker, Słownik obrazów i symboli biblijnych, dz. cyt., s. 123.

15 M. Lurker, Słownik obrazów i symboli biblijnych, dz. cyt., s. 123.

16 D. Forstner, Świat symboliki chrześcijańskiej, tłum. P. Pachciarek, R. Turzyński, W. Zakrzewska, Warszawa 1990, s. 464.

17 M. Lurker, Słownik obrazów i symboli biblijnych, s. 164. 
od temperatury i nasłonecznienia. Bez odpowiednio długiego okresu ciepła i działania promieni słonecznych roślina nie jest w stanie wydać pełnowartościowych owoców. Wiedzę tę przełożyła na sytuację dojrzewania duszy. Poniższy krótki opis jest bardzo bogatą metaforą duchowej pracy człowieka jako pracy ogrodnika dbającego o jakość owoców, a w dalszej perspektywie - o zdrowie swoich bliźnich, których będzie nimi karmił. Widzimy także, że Faustyna ma świadomość, że życie chrześcijanina może być dla innych pokarmem nawet po jego śmierci - poprzez wypraszane łaski, moc ofiary, świadectwo życia, zapisane słowa, wierność misji.

W głębokiej ciszy, przy Twoim miłosiernym Sercu, w tych rekolekcjach dojrzewa ma dusza. W czystych promieniach Twojej miłości zmieniła dusza moja swą cierpkość i stała się ow ocem słodkim i dojrzałym. Teraz mogę być całkowicie pożyteczna Kościołowi przez osobistą świętość, która drgnie życiem w całym Kościele, gdyż wszyscy stanowimy jeden organizm w Jezusie; dlatego wysilam się, aby ziemia serca mojego rodziła owoce d o b r e, choć może nigdy oko ludzkie ich nie dostrzeże, jednak przyjdzie dzień, że się pokaże, że tym owocem karmiło się i karmić się będzie wiele dusz [Dz. 1364; por. 605].

W czasie jednej nauki rzekł do mnie Jezus: W gronku wybranym jesteś słodką jagodą; pragnę, aby sok, który krąży w tobie, udzielił się in nym duszom [Dz. 393]. Musisz być zniszczona w tej tajni, gdzie oko ludzkie nigdy nie sięga, a wtenczas będziesz Mi ofiarą miłą, całopalną, pełną słodyczy i woni, a moc twoja będzie potężna, za kim prosić będziesz [1767].

Oba przykłady odsyłają nas do symboliki tłoczni, w której z winogron (bądź innych owoców) wyciska się sok na wino - aby go uzyskać, owoce muszą być najpierw z n is zc zon e. Stąd symbol tłoczni jako przemiany - a połączony w chrześcijaństwie z opisem męki Chrystusa odsyła do przemiany eucharystycznej i wzbogaca tę symbolikę o kolejne sensy. Tłocznia jest tu bowiem symbolem ołtarza ${ }^{18}$.

Na pierwszy rzut oka skojarzenia te wydają się dalekie - a to dlatego, że słowo jagoda identyfikujemy dzisiaj głównie z desygnatem leśnych

18 M. Lurker, Słownik obrazów i symboli biblijnych, s. 246, 265. 
borówek. Jego znaczenie jest jednak szersze. W Słowniku języka polskiego pod redakcją Witolda Doroszewskiego czytamy, że jest to 'owoc wielu roślin o mięsistej, soczystej owocni, zawierającej zwykle liczne nasiona w twardej łupinie'. Przytoczony jest tam cytat z poezji Leopolda Staffa: „Grono winne-m przynosił tobie, a ty podniesioną w górę dłonią wieszając nad swą wargą młodą owoc pełny, jagodę rwałaś za jagodą"19. Natomiast leksem gronko to deminutyw od grono, jego znaczenie jest zbieżne z powyższą eksplikacją ${ }^{20}$. W chrześcijaństwie to oczywiście Jezus jest tym najsłodszym owocem, a sokiem dającym życie, zdrowie i poczucie szczęścia jest Jego krew. On sam porównał siebie w Ewangelii do krzewu winnego (J 15, 5), natomiast królestwo Boże do winnicy (Mt 21, 33-39), tak jak wcześniej winnicą został nazwany naród wybrany (Iz 5, 7; Oz 10, 1). Przytoczony cytat dołącza do wielu innych fragmentów Dzienniczka ukazujących sens życia chrześcijanina - służbę Bogu i człowiekowi na wzór Syna Bożego. Mówi o tym choćby zdanie: „O słodka i różana krwi Jezusowa, uszlachetnij krew moją i przeistocz ją we własną swoją krew, niechaj mi się to stanie według Twego upodobania" [Dz. 1575].

Poza wymienionymi odnajdujemy w badanym tekście także zleksykalizowane połączenia z potocznej mowy, które autorka wplata w kontekst religijny: „,słodkie ukojenie”, „rozmawiać ze słodyczą”, ,życzyć słodkiego snu". Nie wychodzą one poza ramy przyjętych w polszczyźnie znaczeń, w której leksem słodki jest używany na określenie łagodności, czułości, miłego charakteru, uczucia szczęścia, ukojenia czy harmonijnych, przyjemnych dźwięków ${ }^{21}$.

\subsection{Smak gorzki}

Spośród smaków nieprzyjemnych św. Faustyna wymienia cierpki i gorzki, o których informują nas nazwy: cierpki (1), cierpkość (1), gorzki (15), gorzkość (5), gorycz (52). Odczucie cierpkości bywa wykorzystywane

19 Słownik języka polskiego, red. W. Doroszewski, Warszawa 1964, reprint z 1996 r., t. 3 , s. 298.

20 Zob. Słownikjęzyka polskiego, dz. cyt., t. 2, s. 1309.

${ }^{21}$ Zob. Słownikjęzyka polskiego, dz. cyt., t. 8, dz. cyt., s. 398. 
do definiowania smaku kwaśnego, smaku skwaśniałego wina, czyli octu ${ }^{22}$. Ze względu na małą liczbę użyć nie poświęcono tej leksyce osobnego akapitu. Uzasadnieniem decyzji jest ten sam kontekst użycia obu nazw jest nim męka Pańska.

Najczęściej spotykamy połączenia: „gorzka męka”, „gorzka męka konania”, „gorzkie konanie”, „gorzkie udręczenie”, „gorzki smutek”, "gorzkość męki” albo „gorycz Jego Boskiego Serca”, „gorycz ogrójcowa”, „gorycze Jezusa”, „kielich goryczy”. Jeśli zaś chodzi o pokarmy, które charakteryzują się takim smakiem, dwa razy znajdziemy połączenie „ocet i żółć” - zawsze przy opisie męki. Ponadto raz występuje odniesienie do niedojrzałego owocu, raz też do sposobu bycia traktowanym przez innych („cierpkie się obchodzenie z nami” - por. Dz. 343).

W słownikach symboli smak gorzki wymieniany jest przy opisie piołunu - półkrzewu znanego jako biała bylica, który rośnie w pustynnej części Izraela ${ }^{23}$. Biblia wspomina o nim dziesięć razy i zawsze wtedy, gdy opisuje sytuacje smutku, bólu i rozpaczy. W Dzienniczku nie ma o nim wzmianki, ale z racji częstego użycia wyrażenia „morze goryczy” znamienny wydaje się cytat z Apokalipsy: „i spadła z nieba wielka gwiazda, płonąca jak pochodnia, a spadła na trzecią część rzek i na źródła wód. A imię gwiazdy zowie się Piołun. I trzecia część wód stała się piołunem, i wielu ludzi pomarło od wód, bo stały się gorzkie" (Ap 8, 10-11). Istnieje jednak duże prawdopodobieństwo, że Faustyna powołała się na jego potoczne, a nie biblijne użycie. Odnajdujemy je w zdaniach: „Matko Boża, dusza Twa była zanurzona w goryczy morzu” [Dz. 315]; „, całe morze goryczy niech zalewa serce moje” [Dz. 943]; „Dusza moja została zalana także morzem goryczy" [Dz. 1657].

Smak gorzki, o którym pisze Faustyna, dotyczy pokarmów o konsystencji cieczy - świadczy o tym większość sformułowań. Powodem może być biblijny kieli ch go ry c zy, bo to on stanowi najczęstsze odniesienie: „dolewać do kielicha goryczy”, „pić gorycz”, „pić kielich goryczy”, „poić serce goryczą”, „przelewać kielich goryczy”, „przyłożyć usta do

22 B. Mitrenga, Zmyst smaku..., dz. cyt., s. 178.

23 B. Szczepanowicz, Atlas roślin biblijnych. Pochodzenie, miejsce w Biblii i symbolika, Kraków 2004, s. 198. 
goryczy kielicha”, „wychylić kielich goryczy”, „wypić kielich goryczy do dna, „wysączyć do dna”, ,zalewać goryczą".

W taki sposób święta pisze zarówno o cierpieniu Jezusa, jak i o swoim cierpieniu, które jest albo współprzeżywaniem Jego męki, albo przyjmowaniem codziennych trudności, upokorzeń w intencji ocalenia grzeszników. Jakkolwiek określa je jako straszne, nie cofa się przed nimi - przyjmuje postawę Jezusa z Ogrójca - chce tak jak On wypełnić wolę Boga Ojca.

\footnotetext{
Wielki Poniedziałek. Prosiłam Pana, aby mi pozwolił wziąć udział w swej bolesnej męce, abym duszą i ciałem odczuła Jego bolesną mękę w tym stopniu, w jakim stworzenie może wziąć udział; o ile to jest możliwe, abym mogła odczuć c ałą gorycz Jego [Dz. 1034, por. 1028]. Pragnę być rozciągnięta tak, jak Ty, Jezu, na krzyżu, pragnę wszystkich mąk i boleści, któreś Ty wycierpiał, p ragnę wypić kielich goryczy do dna [Dz. 1484, por. 1489].

O, dusze grzeszników, zabraliście mi Pana, ale dobrze, dobrze, poznajcie, jak słodki jest Pan, a całe morze goryczy niech zalewa serce moje, wszystkie pociechy Boże oddałam wam [Dz. 943].
}

Z tego względu, że to właśnie wolę Bożą nazywa pokarmem [zob. Dz. 136; 650; 652; 667; 886; 899; 952; 1003], stwierdza niejednokrotnie, że odczuwanie duchowych smaków nie powinno mieć znaczenia: ,Jezu mój, rozkoszy mojego serca, kiedy dusza moja jest przepojona Twoją Boskością, przyjmuję z jednakową równowagą słodycz i gorzkość; jedno i drugie przeminie. Jedną rzecz zachowuję w duszy, to jest miłość Bożą, o nią się ubiegam, a wszystko inne - o tyle, o ile" [Dz. 1245, por. 343; 455].

\section{Mistyczne doświadczenia związane z posiłkami}

Choć mistyczne doświadczenia zawieszają zmysły, jak się okazuje, Bóg chętnie wykorzystuje owe zmysły, aby stały się ich kanałem - objawia się Faustynie nie tylko w kaplicy, ale i w kuchni, nie tylko podczas adoracji, ale i podczas posiłku. To właśnie motyw jedzenia stał się centralnym tematem niezwykłego spotkania z Jezusem, który dzwonił do furty pod postacią ubogiego i głodnego młodzieńca. Gdy Faustyna dała mu kubek zupy z chlebem, odsłonił swe oblicze, mówiąc: „Córko Moja, doszły uszu 
Moich błogosławieństwa ubogich, którzy oddalając się od furty, błogosławią Mi, i podobało Mi się to miłosierdzie twoje w granicach posłuszeństwa, i dlatego zszedłem z tronu, aby skosztować owocu miłosierdzia twego" [Dz. 1312]. Inne niezwykłe zdarzenie jest związane z gotowaniem ziemniaków - trud dźwigania garnków zostaje wynagrodzony nadzwyczajnym przypływem sił i widokiem garnka pełnego róż [por. Dz. 65]. Znamienne są także opisy wewnętrznych przeżyć doświadczanych podczas obiadu czy kolacji:

W czasie posiłku obiadowego w jednym momencie dał mi Bóg poznać wielkość przeznaczenia swego, to jest dał mi poznać bliskość Boga - która na wieki ode mnie odjęta nie będzie - z taką żywością i wyraźnie, że przez długi czas pozostałam w głębokim pogrążeniu się w Jego żywej obecności, upokarzając się przed wielkością Jego [Dz. 1410].

Dziś w refektarzu podczas kolacji uczułam Boże spojrzenie w głąb s we go s e r ca. Tak żywa obecność przeniknęła moją duszę, że chwilę nie zdawałam sobie sprawy, gdzie jestem. Słodka obecność Boża zalewała mi duszę i chwilami nie rozumiałam, co do mnie mówiły siostry [Dz. 1391].

Posiłki (tak jak każde inne zajęcie) są dla świętej sytuacją zanurzoną w Bożej rzeczywistości - polem działania łaski, ćwiczenia się w pokorze, okazywania miłości, składania ofiary, naśladowania Jezusa. Z tych właśnie pobudek oddaje swój podwieczorek [Dz. 1712], przyjmuje pomarańczę [1647], ogranicza posiłki lub pości. Należy przy tym pamiętać, że Faustyna stale miała problemy z trawieniem: „wielkie robiłam wysiłki, aby cośkolwiek zjeść, gdyż pokarmy nudziły mnie. W tym czasie zaczęły mnie także chwytać boleści w kiszkach, wszystkie ostrzejsze pokarmy sprawiały mi niezmierne boleści" [Dz. 1428, por. 1451]. A jednocześnie, jak wspomina matka Borgia Tichy, jej przełożona z Wilna, była bardzo dobrą kucharką, dbającą o estetyczne podanie do stołu: „Jako fachowa i wykwintna kucharka, zawsze w czasie uroczystości domowych obejmowała kierownictwo kuchni"24.

24 Wspomnienia o świętej Siostrze Faustynie Kowalskiej ze Zgromadzenia Matki Bożej Miłosierdzia, oprac. M. E. Siepak ZMBM, Kraków 2011, s. 94. 


\section{Poziomy metaforyzacji}

„Znajomość analogii tak jest konieczna, że bez niej nikt nie może uprawiać metafizyki - a i w innych naukach z jej nieznajomości płynie wiele błędów"25 - pisał Thomas de Vio, komentator św. Tomasza z Akwinu. Analizowane tu słownictwo opisujące zmysły zostało użyte nie inaczej, jak właśnie w celu zbudowania analogii (choć siostra Kowalska nie określiłaby w ten sposób swoich zapisków). W Dzienniczku znajdujemy dwa poziomy metaforyzacji w używaniu leksyki zmysłu smaku. Pierwszy mówi o wykorzystaniu leksyki stanów fizycznych do opisu stanów psychicznych, drugi zaś poziom to wykorzystanie metafor stanu psychicznego do opisu stanów duchowych, religijnych ${ }^{26}$, np.: słodycz miodu - słodycz miłości - słodycz Serca Jezusowego; gorzki smak piołunu - gorzki smutek - gorzka męka duszy. Samo bowiem systemowe znaczenie nazw słodki, gorzki odsyła nas do biologicznej cechy zmysłów i dopiero na ich kanwie tworzymy analogie pomagające nam określić uczucia, emocje i inne stany psychiki, które często są niewyrażalne. Ten potencjał tkwiący w języku człowiek wykorzystywał od zawsze (nie był on domeną jedynie poetów). Stany duszy są tym bardziej niewyrażalne, wymagają więc jeszcze szerszego pola analogii.

Są mistycy, których metafory życia wewnętrznego stanowią bardzo oryginalną twórczość, niezapośredniczoną tak bardzo przez językowy uzus ich czasów i nazewnictwo stanów psychicznych. U Faustyny nie znajdujemy tak oryginalnych analogii - wyzyskane pola semantyczne nie wychodzą poza ramy ówczesnej polszczyzny. Są jedynie wzbogacone o nazewnictwo biblijne i liturgiczne. Niewątpliwie jednak urzeka widoczna w Dzienniczku celność porównań i łatwość tworzenia tych metaforycznych pomostów między sferą ciała i ducha. Uwidacznia się ona w różnych typach połączeń wyrazowych: „karmić się wolą Bożą”, „kosztować słodyczy Bożych”, „mieć duszę zalaną morzem goryczy”, „pić

25 Cyt. za: A. Maryniarczyk SDB, o przyczynach, partycypacji i analogii, Lublin 2005, s. 71 (Zeszyty z Metafizyki, 6).

${ }_{26}$ Zob. I. Rutkowska, Niepojęty świat duszy. Język doświadczeń mistycznych św. Faustyny Kowalskiej, Tarnów 2017, s. 385-386. 
kielich goryczy”, „pocieszać w gorzkim smutku”, „posilać się Chlebem mocnych", „słodko rozmawiać z Jezusem”. Tak użyte słownictwo świadczy także o ucieleśnieniu duszy, która „czuje smak”, „karmi się”, „,kosztuje”, ,nasyca się”, ,pije”, ,posila się”. Nie dziwi nas to choćby z jednego powodu - nazwa dusza bywała stosowana na określenie człowieka (m.in. jako członka Kościoła, parafianina). Nie jest to jedynie domena tekstów teologicznych, tego rodzaju metaforykę podaje także Słownikjęzyka polskiego ${ }^{27}$.

Leksyka ze sfery zmysłu smaku stanowi definiens pojęć ze sfery sacrum: 'miłosierdzie Boże - źródło duchowych słodyczy, słodkie ukojenie dla serc udręczonych, słodka nadzieja dla człowieka grzesznego'; 'wola Boża - pokarm duszy w czasie ziemskiej wędrówki do ojczyzny niebieskiej'. Definicja duchowej rzeczywistości czasem oddawana jest także przez alegoryczny obraz, zbliżony do ewangelicznej przypowieści [zob. Dz. 641]. Te pokarmowe konotacje wzmacnia (i uprawomocnia jednocześnie) sam ryt Eucharystii, w której wierni fizycznie spożywają opłatek, który w wierze przyjmują jako Ciało Chrystusa. Pokarm liturgiczny najściślej łączy w sobie te dwie sfery - cielesną i duchową. To słownictwo jest także w Dzienniczku najliczniejsze: Komunia Święta występuje 142 razy, hostia - 115 razy, opłatek - 11 razy. Natomiast 18 razy Komunia Święta występuje pod nazwą chleba (jako: „Chleb anielski”, „Chleb dziewiczy”, „Chleb mocnych”, „Chleb żywy). Przewyższa o 100 elementów słownictwo opisujące wszelkie aspekty obu smaków (liczące razem 186 elementów).

\section{Zmysł smaku jako element rozwoju duchowego}

Sama analiza zaproponowanej leksyki i kontekstów jej użycia jest o tyle zasadna dla chrześcijanina, o ile prowadzi go do głębszych, teologicznych sensów. Gdy zaś mowa o odczuciach zmysłowych, nie sposób nie przywołać terminologii św. Jana od Krzyża: „noc czynna zmysłów, noc bierna zmysłów".

27 Słownikjęzyka polskiego, dz. cyt., t. 2, s. 436-437. 
Czynne oczyszczenie zmysłów „polega na uporządkowaniu działania władz zmysłowych w stosunku do ostatecznego celu chrześcijanina. Owocem owego uporządkowania ma być całkowite poddanie zmysłów działaniu rozumu i woli, które ze swej strony powinny się całkowicie i doskonale podporządkować nadprzyrodzonej wierze. [...] Za środek do walki z pożądaniem rzeczy doczesnych autorzy uważają zgodnie z doktryną Doktora Mistycznego stałe i niezłomne pragnienie doskonałego naśladowania Jezusa Chrystusa” ${ }^{28}$. „Poddając się biernemu oczyszczeniu zmysłów, człowiek wyzwala się od wad swej części zmysłowej, staje się natomiast wrażliwy na dar kontemplacji”29.

Jak się okazuje, zestawienie kwestii zmysłu smaku zawartej w pismach polskiej świętej z początku XX wieku z treściami hiszpańskiego karmelity z XVI wieku może być bardzo zasadne. Nie jest też nowe - między innymi w tym kluczu teologicznym rozpatrywał duchowość św. Faustyny ks. Stanisław Urbański. Jak dowodził, krakowska święta jest „wzorem pełnego zjednoczenia z Bogiem"30. Po zestawieniu wyekscerpowanych z Dzienniczka cytatów odnoszących się do zmysłu smaku i fragmentów, do których odnosi się ks. Urbański, widzimy, jak ich treści są spójne. Wynika z tego, że nawet leksyka tworząca językowy obraz smaku wpisuje się w dynamikę duchowego rozwoju i znaczy kolejne jego etapy.

Odnosząc się do podanych wyżej krótkich opisów nocy zmysłów, można uznać, że pierwszym etapem na drodze duchowego wzrastania jest umiejętność uporządkowania zmysłowych odczuć, aby uzyskać równowage ducha - czyli oddzielenie dobrych od złych, przyjemnych od przykrych, rozpoznanie, że nie wszystkie odczucia przyjemne są dobre, a przykre są złe, a także znalezienie analogii między odczuciem zmysłowym a duchowym. Pisze o tym św. Faustyna pod numerem 455: „Kiedy mnie dotyka jakie cierpienie, to ono już mi teraz nie sprawia goryczy ani wielkie pociechy nie unoszą mnie; owładnięta jestem pokojem i równością ducha, która płynie z poznania prawdy".

Etap ten polega jednocześnie na poznawaniu, w jaki sposób odczucia zmysłowe dotyczyły Jezusa w czasie Jego ziemskiego życia - tak, aby móc naśladować Go w najmniejszych, nawet cielesnych odruchach. Jak

S. Urbański, Teologia życia mistycznego, Warszawa 1999, s. 163-164.

S. Urbański, Teologia życia mistycznego, dz. cyt., s. 173.

S. Urbański, Mistyczny świat ducha, Warszawa 2000, s. 11. 
pokazują mistycy, poznanie tych prawd nie dokonuje się na drodze intelektualnej analizy, ale poprzez doświadczenia, nierzadko bolesne. Jak odkryła Faustyna, tym „najsmaczniejszym”, bo jedynym potrzebnym pokarmem duszy (który notabene był pokarmem Jezusa) ma być wola Boża: „Na jedno słowo uważam i z tym jednym się zawsze liczę, to jedno mi jest wszystkim, tym żyję i z tym umieram, a to jest święta wola Boża. Ona jest mi pokarmem codziennym; cała dusza moja jest wsłuchana w życzenia Boże, pełnię zawsze to, czego Bóg ode mnie żąda, chociaż nieraz drży natura moja i czuję, że wielkość ich przechodzi siły moje" [Dz. 652].

Co należy podkreślić, doświadczenia duszy to doświadczenia przeżywane na drodze formowania się miłosnej relacji z Bogiem. Widzimy to jasno u św. Faustyny - im większa jest jej miłość do Jezusa, tym większe pragnienie kosztowania gorzkości Jego męki, która tylko dzięki miłości nazywana jest słodyczą: „i doznałam słodyczy w tym cierpieniu, i zapragnęła dusza moja tego słodkiego konania, którego nie zamieniłabym za żadne skarby świata" [Dz. 1454; por. Dz. 1609].

Efektem oczyszczenia zmysłów zewnętrznych ma być przede wszystkim ich uciszenie, zobojętnienie na emocje, które wywołują, tak aby nic nie zakłócało mistycznej unii z Bogiem. „Pokój wewnętrzny jest jednym z podstawowych skutków duchowego małżeństwa, a zarazem kresem nocy ducha" - pisze ks. Urbański ${ }^{31}$. W Dzienniczku znajdujemy poświadczenie, że Faustyna doszła do tego etapu oczyszczenia. Mówią o tym zdania:

Jezu mój, rozkoszy mojego serca, kiedy dusza moja jest przepojona Twoją Boskością, przyjmuję z jednakową równowagą słodycz i gorzkość; jedno i drugie przeminie. Jedną rzecz zachowuję w duszy, to jest miłość Bożą, o nią się ubiegam, a wszystko inne - o tyle, o ile [Dz. 1245]. Komunię świętą przyjmuję na sposób niejako anielski. Dusza moja zalana światłem Bożym i karmi się nim, uczucia są zamarłe - jest to łączenie się z Panem na wskroś duchowe, jest to wielka przewaga ducha nad naturą [Dz. 1278].

31 S. Urbański, Mistyczny świat ducha, dz. cyt., s. 148. 


\section{Zakończenie}

Święta Faustyna zaprasza swoich czytelników do tego, aby rozsmakowali się w Bogu i wznieśli się ponad naturalne odczucia przyjemności i nieprzyjemności. Proponuje inną interpretację smaku oraz spożywanych pokarmów - zanurzoną w treściach religijnych. Wskazuje, że tak jak chrześcijanin ma obowiązek dbać o odpowiednie pożywienie dla ciała (nie tylko smaczne, ale i dające siłę), tak też powinien - analogicznie - zadbać o pokarm dla duszy. Mówi wprost - tym pokarmem jest przede wszystkim wola Boża, ponadto łaski Boże, mądrość Boża, miłosierdzie Boże, światło Boże. Dusza karmi się tą strawą głównie podczas Eucharystii, przyjmując Komunię Świętą, ale i w czasie adoracji, modlitwy, rekolekcji.Jednocząc się z Bogiem, kosztuje słodyczy, czyli „szczęścia niebian" [por. Dz. 507], ale nie stroni też od innych pokarmów - znanych Ukrzyżowanemu. Rozważając Jego mękę, tak jak On wychyla do dna kielich goryczy, godząc się na to, że w swym ziemskim życiu będzie doświadczać jedynie gorzkich uczuć - smutku, odrzucenia, upokorzenia, choroby.

W takim obrazowaniu duchowej rzeczywistości święta wykorzystuje najprostsze słownictwo związane z pojęciem smaku, nieodbiegające od metaforyki znanej z mowy potocznej, a wzbogaconej o słownictwo biblijne i liturgiczne. Wskazywana przez nią analogia nie ma jednak na celu zbudowania kontrastu: ciało-dusza. Język opisujący cechy ciała służy temu, aby jak najbardziej przystępnie opisać świat duszy i przybliżyć człowiekowi obrazBoga. Trzeba jednak podkreślić, iż niejest tojej celowy pisarski zabieg, bo i Dzienniczek nie stanowi traktatu, a żywy zapis duchowej codzienności.

Przedstawiony temat stanowi jedynie małą cząstkę podobnych analogii. W ten sam sposób można rozpisać wszystkie zmysły i części ciała. Można w tym momencie zapytać o cel takich analiz. Jednym z nich jest chęć zwrócenia uwagi na cielesne odniesienia u mistyków, postrzeganych stereotypowo jako osoby nieracjonalne i unoszące się nad ziemią. Innym - włączenie się w żywy współcześnie dyskurs na temat ciała jako głównego punktu odniesienia, orientacji, czytania świata (tak diagnozują wiek XXI medioznawcy ${ }^{32}$ ). Pomysł ten nie jest nowy, o czym świadczy

32 Zob. R. Debray, Wprowadzenie do mediologii, tłum. A. Kapciak, Warszawa 2010, s. 61. 
choćby praca Antona Marczyńskiego Ciało / mistyka. Wstęp do ontologii cielesności ${ }^{33}$ czy inne teologiczne artykuły ${ }^{34}$. Novum stanowić jednak może samo badanie polszczyzny pod kątem jej potencji w obrazowaniu owych niewyrażalnych, mistycznych tajemnic.

\footnotetext{
3 A. Marczyński, Ciało / mistyka. Wstęp do ontologii cielesności, Kraków 2016.

34 Zob. W. Zyzak, Znaczenie ciała w duchowości Karola de Foucauld, „Polonia Sacra” 21 (2017) nr 3 (48), s. 129-145.
} 


\section{Summary}

Słodko-gorzki smak mistyki. Leksyka zmysłu smaku w Dzienniczku św. Faustyny Kowalskiej

Artykuł ma charakter badawczy. Jego celem jest odkrycie znaczeń, jakie św. Faustyna nadała zmysłowi smaku, a zarazem ukazanie poziomów metaforyzacji użytego przez nią słownictwa. Analiza jakościowo-ilościowa dotyczy leksyki opisującej smaki słodki i gorzki - są to bowiem jedyne nazwy smaków wskazane przez autorkę Dzienniczka. Jak wykazała analiza, większość słownictwa z tego pola została użyta do zobrazowania relacji duszy z Bogiem. Smak słodki posłużył na określenie samego Boga, obcowania z Nim. Smak gorzki konotuje głównie mękę Pańską i cierpienia, jakie Faustyna znosi w intencji dusz. W tworzeniu analogii między ciałem a duszą wyzyskuje ona słownictwo potoczne, łącząc je z biblijnym i liturgicznym. Jak wskazuje, dusza także ma swój pokarm - są nim wola Boża, łaska, mądrość Boża, a także Boże miłosierdzie.

Słowa kluczowe: semantyka, mistyka, św. Faustyna Kowalska, zmysł smaku

The Bittersweet Taste of Mysticism. The Lexis of the Sense of Taste in The Diary by St Faustina Kowalska

The article is of analytical character. Its aim is to discover the meanings which St Faustina attributed to the sense of taste as well as to reveal the levels of metaphorization of the vocabulary she used. The quality and quantity analysis involves the lexis which describes the sweet and bitter tastes - those are actually the only names of tastes indicated by the author of The Diary. As the analysis revealed, most of the vocabulary from this area was used to depict the relationship between the soul and God. The sweet taste served to define God Himself, communing with Him. The bitter taste is associated principally with Lord's Passion and suffering which Faustina experiences in the intention of the souls. While creating the analogy between the body and the soul, she exploits colloquial vocabulary, combining it with the biblical and liturgical lexis. As she indicates, the soul has also its food - this is God's will, grace, God's wisdom and God's mercy.

Keywords: semantic, mysticism, St Faustina Kowalska, sense of taste 


\section{Bibliografia}

Bartmiński J., Językowe podstawy obrazu świata, Lublin 2007.

Beckmann B., Wprowadzenie, w: Teresa Benedykta od Krzyża, Drogi poznania Boga, Kraków 2006, s. 15-52.

Debray R., Wprowadzenie do mediologii, tłum. A. Kapciak, Warszawa 2010.

Encyklopedia językoznawstwa ogólnego, red. K. Polański, Wrocław 2003.

Forstner D., Świat symboliki chrześcijańskiej, tłum. P. Pachciarek, R. Turzyński, W. Zakrzewska, Warszawa 1990.

Kominek A., Jak skutecznie przekazywać prawdę o miłosierdziu Bożym? Orędzie św. Faustyny Kowalskiej w praktyce katechetycznej, w: Komunikacja i tekst w perspektywie rozwojowej i dydaktycznej, red. J. Porayski-Pomsta, Warszawa 2005, s. 261-273 (Studia Pragmalingwistyczne, 4).

Kowalska M. F., Dzienniczek. Miłosierdzie Boże w duszy mojej, Warszawa 2006.

Kopaliński W., Stownik symboli, Warszawa 1999.

Lurker M., Słownik obrazów i symboli biblijnych, tłum. K. Romaniuk, Poznań 1989.

Marczyński A., Ciało / mistyka. Wstęp do ontologii cielesności, Kraków 2016.

Maryniarczyk A., O przyczynach partycypacji i analogii, Lublin 2005 (Zeszyty z Metafizyki, 6).

Mitrenga B., Zmysł smaku. Studium leksykalno-semantyczne, Katowice 2014.

Pismo Święte Starego i Nowego Testamentu, oprac. Zespół Biblistów Polskich z inicjatywy Benedyktynów Tynieckich, Poznań 2000.

Rutkowska I., Niepojęty świat duszy. Język doświadczeń mistycznych św. Faustyny Kowalskiej, Tarnów 2017.

Stownik jezzka polskiego, t. 2, 3, 8, red. W. Doroszewski, Warszawa 1964, reprint z 1996.

Szczepanowicz B., Atlas roślin biblijnych. Pochodzenie, miejsce w Biblii i symbolika, Kraków 2004.

Uniwersalny słownikjęzyka polskiego, red. S. Dubisz, Warszawa 2003.

Urbański S., Teologia życia mistycznego, Warszawa 1999.

Urbański S., Mistyczny świat ducha, Warszawa 2000.

Wspomnienia o Świętej Siostrze Faustynie Kowalskiej ze Zgromadzenia Matki Bożej Miłosierdzia, oprac. M. E. Siepak ZMBM, Kraków 2011.

Zyzak W., Znaczenie ciała w duchowości Karola de Foucauld, „Polonia Sacra” 21 (2017) nr 3 (48), s. 129-145. 